\title{
The relationship between plasma cholesterol and lipids and qualitative indicators of the ejaculate of Holstein and Czech Spotted bulls*
}

\author{
L. Máchal \\ Mendel University of Agriculture and Forestry \\ Zemédèlská 1, 61300 Brno, Czech Republic
}

(Reccived 15 December 2000; accepted 20 April 2001)

\begin{abstract}
The correlations between plasma cholesterol, total lipid concentrations and the qualitative indicators of the ejaculate were investigated in 24 active breeding bulls $(13$ Holstein and 11 Czech Spotted) over a period of 12 months. No significant differences were observed in cholesterol (3.35 and $3.21 \mathrm{mmol}^{-1} \mathrm{f}^{-1}$, respectively) or total lipid ( 3.70 and $\left.3.69 \mathrm{g.t} .^{-1}\right)$ concentrations between the two breeds. The average volume of the ejaculate was $1.15 \mathrm{~cm}^{3}$ higher (i.e. $18.4 \%$ ) in the Holstein bulls (7.39 and $6.24 \mathrm{ml}$, respectively).

In the 12-month period, a highly significant $(\mathrm{P}<0.01)$ correlation was found between the plasma cholesterol concentration and the following indicators: sperm motility $\left(r_{p}=0.25\right)$, cjaculate volume $\left(r_{p}=0.24\right)$, and sperm concentration $\left(r_{p}=-0.25\right)$. The correlations between total plasma lipids and the above indicators were: sperm motility $\left(r_{p}=0.13\right)$, ejaculate volume $\left(r_{p}=0.13\right)$ and sperm concentration $\left(r_{p}=-0.11\right)$. These values were not, however, significant.

KEY WORDS: bulls, blood plasma, cholesterol, total lipids, ejaculate volume, sperm motility, sperm concentrations
\end{abstract}

\section{INTRODUCTION}

A number of factors and influences, from genetic through technological to health-related, considerably affect the reproductive performance of bulls. If we investigate the quality and quantity of the ejaculates of bulls used in insemination

* Funded by the MSM 432100001 
stations, we will see that the quality of one and the same bull changes. The average values of qualitative and quantitative ejaculate indicators reported by different authors slightly differ too.

Analogous to the changes in qualitative and quantitative indicators of the ejaculates of bulls, the concentrations of total lipids and cholesterol in their plasma change too. Plasma cholesterol and total lipid levels in bulls are based on the normal values for cattle presented by Vrzgula et al. (1990) (the concentration of total lipids from 2.00 to $5.20 \mathrm{~g} . \mathrm{l}^{-1}$ and cholesterol from 2.60 to $\left.5.20 \mathrm{mmol} . \mathrm{l}^{-1}\right)$. However, these are only benchmark values. For instance, Alvarez et al. (1986) reported that the average concentration of total plasma lipids and cholesterol in bulls used for sperm collection was only $1.97{\mathrm{~g} . \mathrm{I}^{-1}}$ and $2.57 \mathrm{mmol}^{-\mathrm{I}^{-1}}$, respectively. Bulla et al. (1991) dealt with the concentration of plasma cholesterol in bulls and reported that the average concentration of cholesterol in the plasma of bulls at the age of 90 to 430 days ranged between 2.29 and $2.36 \mathrm{mmol}^{-1}$. Stevanovič et al. (1997) discovered much higher values of cholesterolaemia, i.e. $5.91 \mathrm{mmol}^{-1} \mathrm{f}^{-1}$ in the plasma of Black Pied (Friesian) bulls. Seoane et al. (1999) found that breed determined plasma cholesterol concentrations in bulls. Santos et al. (1998) and Oprządek et al. (2000) stated that the concentration of plasma cholesterol depends on feeding.

The objective of the present study was to define the dynamics of cholesterol and total lipids in plasma, and their correlation with the ejaculate quality of bulls of the Holstein and Czech Spotted breeds.

\section{MATERIAL AND METHODS}

The relationship between the reproductive performance of breeding bulls and selected biochemical indicators of plasma was investigated in 24 active breeding bulls (aged from two to four years) used for semen collection at an insemination station, i.e. 13 Holstein and 11 Czech Spotted bulls. One bull was culled towards the end of the experiment (due to the results of progeny testing) and two bulls were transferred to another insemination station.

All of the bulls were housed in stanchion stables. Ejaculate for the production of insemination doses was collected two times a week. The bulls were fed a uniform feed ration.

Investigations were conducted for a twelve-month period, from May to April of the following year. The ejaculate was collected periodically and the following indicators were determined: sperm motility, sperm concentration, ejaculate volume, total sperm count in ejaculate (TNS), and the total number of motile sperm cells in the ejaculate (TNMS). In addition, blood samples were taken from the bulls every month to determine cholesterol and total lipid concentrations (284 samples over the entire twelve-month period). Venous blood was taken from the vena 
coccygea mediana, always between 8 and $11 \mathrm{a} . \mathrm{m}$. The concentrations of the selected indicators (cholesterol and total lipids) in the plasma were determined colorimetrically within 24 h using Bio - LA kits (Lachema, Czech Republic).

The dynamics of the changes were evaluated by calculating phenotypic correlation and by variance analysis.

\section{RESULTS AND DISCUSSION}

The average values for cholesterol and total lipid concentrations of blood plasma and qualitative indicators of the ejaculate of the breeding bulls in individual calendar months, the dynamics of the data during the entire 12-month period, including the significance of differences in the respective months, are given in Table 1. During the twelve months of the study, the average volume of the ejaculate of all the bulls was $6.89 \mathrm{~cm}^{3}$, the sperm concentration was $1.13\left(\mathrm{~mm}^{-3}\right) .10^{6}$, and sperm motility, $69.3 \%$. The average total number of sperm cells in the ejaculate (decisive for the number of insemination doses made) was $7.65 .10^{9}$, and the total number of active sperm cells in the ejaculate was $5.37 .10^{9}$.

Over the course of the 12 months, significant differences were observed in all of the quality indicators of the ejaculate; the differences were highly significant $(\mathrm{P}<0.01)$ between sperm concentration and ejaculate volume (Table 1). The lowest sperm motility $(67.0 \%)$ was observed towards the end of the period of investigation, i.e. in March 2000. In December 1999 and January 2000, the average ejaculate volume $\left(4.56 \mathrm{~cm}^{3}\right)$, total number of sperm cells in the ejaculate $\left(5.40 .10^{9}\right)$, and total number of active sperm cells in the ejaculate $\left(3.55 .10^{9}\right)$ were the lowest. In contrast, sperm concentration was the lowest at the beginning of the investigation (July $\left.1999-0.93\left(\mathrm{mil}^{-3}\right) \cdot 10^{6}\right)$. The highest average qualitative and quantitative indicators of the ejaculate were observed in exactly opposing periods. At the beginning of the investigations, in May and July 1999, average sperm motility was the highest $(71.0 \%)$. The highest ejaculate volume was found in May to September $1999\left(7.85\right.$ to $\left.8.82 \mathrm{~cm}^{3}\right)$, the total number of sperm cells in the ejaculate as well as the total number of active sperm cells in the ejaculate was the highest in the middle of this period (9.31.10 and $6.49 .10^{9}$, respectively). The highest average sperm concentration was recorded at the end of the study (April $\left.2000-1.42\left(\mathrm{~mm}^{-3}\right) .10^{6}\right)$.

The average cholesterol and total lipid concentrations during the 12 months of the investigations were $3.29 \mathrm{mmol} . \mathrm{l}^{-1}$ and $3.70 \mathrm{~g} . \mathrm{l}^{-1}$, respectively. These figures are

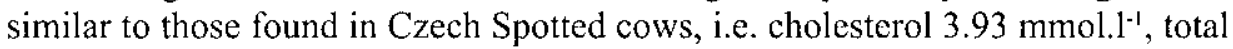
lipids $3.16 \mathrm{mmol}^{-1}{ }^{-1}$, respectively (Máchal et al., 1999). The differences in both of the blood plasma indicators during the 12 -month period were highly significant $(\mathrm{P}<0.01)$. In the individual indicators, the differences between these values were balanced. The total plasma lipid concentration of the bulls was the lowest towards 
TABLE 1

The average values of selected biochemical blood indicators and qualitative indicators of ejaculate of breeding bulls in the individual months and the significance of the differences between them (unifactorial variance analysis)

\begin{tabular}{|c|c|c|c|c|c|c|c|c|c|c|c|c|c|c|c|}
\hline \multirow[t]{2}{*}{ Month } & \multirow[t]{2}{*}{$\mathrm{n}$} & \multicolumn{2}{|c|}{$\begin{array}{c}\text { Ejaculate } \\
\text { volume } \mathrm{cm}^{3}\end{array}$} & \multicolumn{2}{|c|}{$\begin{array}{l}\text { Concentration of } \\
\text { sperms } \mathrm{mm}^{3} .10^{6}\end{array}$} & \multicolumn{2}{|c|}{$\begin{array}{c}\text { Sperm motility } \\
\% \\
\end{array}$} & \multicolumn{2}{|c|}{$\begin{array}{c}\text { Total number of } \\
\text { sperms } .10^{\circ} \\
\end{array}$} & \multicolumn{2}{|c|}{$\begin{array}{c}\text { Total number of } \\
\text { motile sperms } .10^{9}\end{array}$} & \multicolumn{2}{|c|}{$\begin{array}{c}\text { Cholesterol } \\
\text { mmo.1 }\end{array}$} & \multicolumn{2}{|c|}{$\begin{array}{l}\text { Total lipids } \\
\text { g. } 1^{-1}\end{array}$} \\
\hline & & $x$ & $\mathrm{Sx}$ & $\mathrm{x}$ & Sx & $\mathrm{x}$ & Sx & $x$ & Sx & $\mathrm{x}$ & Sx & $\mathrm{x}$ & $\mathrm{Sx}$ & $x$ & $\mathrm{Sx}$ \\
\hline VI. 1999 & 24 & 7.85 & 2.65 & 0.96 & 0.19 & 70.0 & 2.41 & 7.83 & 3.17 & 5.52 & 2.23 & 3.51 & 0.35 & 3.95 & 0.54 \\
\hline VII.1999 & 24 & 8.67 & 3.12 & 0.93 & 0.21 & 71.2 & 3.76 & 8.01 & 3.31 & 5.76 & 2.54 & 3.56 & 0.40 & 3.96 & 0.85 \\
\hline VIII. 1999 & 24 & 8.12 & 2.92 & 0.94 & 0.20 & 69.5 & 7.67 & 7.51 & 2.59 & 5.37 & 1.95 & 3.44 & 0.35 & 3.61 & 0.51 \\
\hline XI. 1999 & 24 & 6.39 & 2.52 & 1.26 & 0.27 & 68.8 & 4.33 & 8.02 & 3.68 & 5.58 & 2.59 & 3.43 & 0.37 & 3.63 & 0.45 \\
\hline XII. 1999 & 24 & 4.56 & 2.48 & 1.24 & 0.25 & 66.3 & 8.34 & 5.40 & 2.61 & 3.55 & 1.37 & 2.90 & 0.51 & 3.54 & 0.40 \\
\hline I. 2000 & 24 & 5.80 & 3.58 & 1.21 & 0.34 & 69.2 & 3.47 & 7.03 & 4.57 & 4.82 & 3.10 & 3.02 & 0.70 & 3.60 & 0.55 \\
\hline II. 2000 & 23 & 5.53 & 2.91 & 1.23 & 0.28 & 69.4 & 2.72 & 6.70 & 3.65 & 4.98 & 2.52 & 2.91 & 0.52 & 3.49 & 0.37 \\
\hline III. 2000 & 23 & 4.82 & 3.25 & 1.25 & 0.40 & 67.3 & $4.5 i$ & 6.24 & 4.88 & 4.21 & 3.25 & 3.23 & 0.49 & 3.49 & 0.32 \\
\hline IV. 2000 & 22 & 5.67 & 4.04 & 1.42 & 0.41 & 70.0 & 3.33 & 8.04 & 5.53 & 5.65 & 3.86 & 3.23 & 0.53 & 3.50 & 0.31 \\
\hline
\end{tabular}

$+\mathrm{P}<0.05 ;++\mathrm{P}<0.01$ 
the end of the 12-month period (February and March $2000-3.49$ g. $1^{-1}$ ) and the highest at the beginning (May $1999-4.08 \mathrm{~g}^{-1^{-1}}$ ). In July 1999, the $3^{\text {rd }}$ month of the investigations, the average cholesterol concentration was the highest $\left(3.56 \mathrm{mmol}^{-1} \mathrm{l}^{-1}\right)$. Similarly as the total lipid concentrations, the average cholesterol concentrations were the lowest towards the end of the 12-month period, i.e. in February 2000 ( 2.90 and $2.91 \mathrm{mmol}^{-1} \mathrm{l}^{-1}$, respectively).

The average plasma cholesterol and total lipid concentrations found in the bulls are in agreement with data reported by Vrzgula et al. (1990) and Bulla et al. (1991). However, Stevanovič et al. (1997) found a higher average concentration of plasma cholesterol in Holstein bulls, i.e. $5.91 \mathrm{mmol}^{-1} \mathrm{I}^{-1}$, while Alvarez et al. (1986) reported considerably lower values of cholesterol and total lipids, even below the threshold of normal values (cholesterol and total lipids $2.57 \mathrm{mmol}^{-\mathrm{l}^{-1}}$ and $1.97 \mathrm{mmol}^{-1} \mathrm{f}^{-1}$, respectively). Unfortunately, they did not provide any data on ejaculate production.

Figure 1 presents the average plasma cholesterol and total lipid concentrations, qualitative indicators of the ejaculate in the individual months, and the dynamics of these values during the entire twelve-month period for both Czech Spotted and

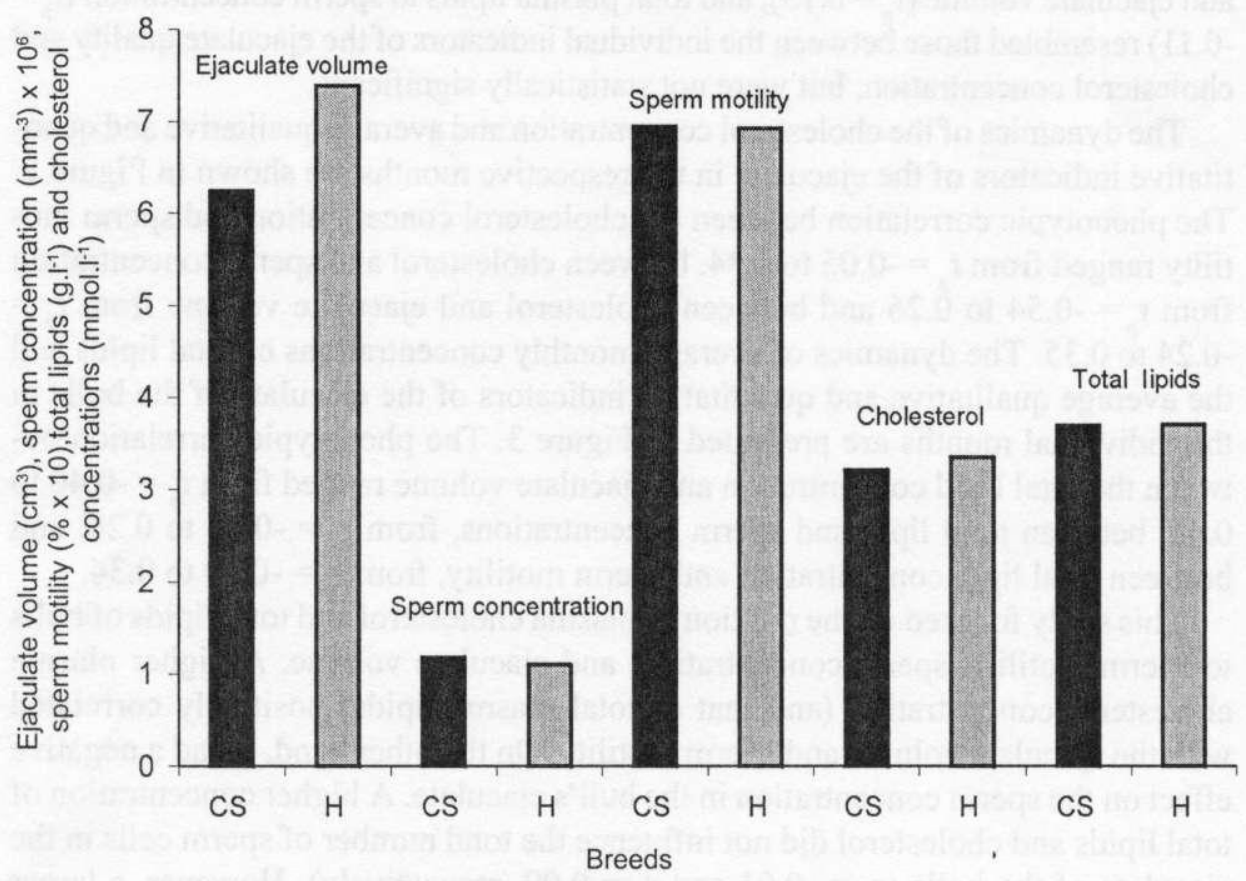

Figure 1. The average values of the qualitative indicators of ejaculates, blood total lipids and cholesterol concentrations in the bulls of Czech Spotted (CS) and Holstein (H) breeds 
Holstein bulls. No significant differences were observed between the average values of plasma cholesterol and total lipids, similarly as sperm motility and concentration (these findings are not in agreement with the results of Seoane et al. (1999) who pointed out that the plasma cholesterol concentrations of bulls depended on the breed).

The average volume of the ejaculate was $1.15 \mathrm{ml}$ (i.e. $18.4 \%$ ), higher in the Holstein than in the Czech Spotted bulls (i.e. 7.39 and $6.24 \mathrm{ml}$, respectively). This difference was positively reflected in the total higher number of sperm cells in the ejaculate and total number of motile sperm cells in the ejaculate of Holstein bulls.

Table 2 gives the dynamics of the phenotypic correlation between the individual criteria (total lipids and cholesterol concentrations in the plasma and qualitative and quantitative indicators of the ejaculate) and the average values during the 12 months of the investigations. A highly significant positive correlation $(\mathrm{P}<0.01)$ was found between the plasma cholesterol concentration and sperm motility $\left(r_{p}=0.25\right)$ and plasma cholesterol concentration and ejaculate volume $\left(r_{p}=0.24\right)$. A highly significant negative correlation $(\mathrm{P}<0.01)$ was found between the plasma cholesterol concentration and sperm concentration $\left(r_{p}=-0.25\right)$ during this period. The correlations between total plasma lipids and sperm motility $\left(r_{p}=0.13\right)$, total plasma lipids and ejaculate volume $\left(r_{p}=0.13\right)$, and total plasma lipids to sperm concentration $\left(r_{p}=\right.$ -0.11 ) resembled those between the individual indicators of the ejaculate quality and cholesterol concentration, but were not statistically significant.

The dynamics of the cholesterol concentration and average qualitative and quantitative indicators of the ejaculate in the respective months are shown in Figure 2. The phenotypic correlation between the cholesterol concentration and sperm motility ranged from $r_{p}=-0.05$ to 0.34 , between cholesterol and sperm concentration from $r_{p}=-0.54$ to 0.26 and between cholesterol and ejaculate volume from $r_{p}=$ -0.24 to 0.35 . The dynamics of average monthly concentrations of total lipids and the average qualitative and quantitative indicators of the ejaculate of the bulls in the individual months are presented in Figure 3. The phenotypic correlation between the total lipid concentration and ejaculate volume ranged from $r_{p}=-0.40$ to 0.45 , between total lipid and sperm concentrations, from $r_{p}=-0.36$ to 0.26 , and between total lipid concentration and sperm motility, from $r_{p}=-0.29$ to 0.34 .

This study focused on the relation of plasma cholesterol and total lipids of bulls to sperm motility, sperm concentration, and ejaculate volume. A higher plasma cholesterol concentration (and that of total plasma lipids) positively correlated with the ejaculate volume and sperm motility. On the other hand, it had a negative effect on the sperm concentration in the bull's ejaculate. A higher concentration of total lipids and cholesterol did not influence the total number of sperm cells in the ejaculate of the bulls $\left(r_{p}=-0.01\right.$ and $r_{p}=0.09$, respectively). However, a larger volume of the ejaculate has an advantage as it brings more energy resources and protection for the sperm cells. 
TABLE 2

The calculated correlation between the concentrations of total plasma lipids, cholesterol and qualitative and quantitative indicators of the ejaculate of breeding bulls in the course of 12 months

\begin{tabular}{|c|c|c|c|c|c|c|c|c|c|c|}
\hline \multirow[b]{2}{*}{ Month } & \multicolumn{3}{|c|}{ Cholesterol } & \multicolumn{2}{|c|}{ Cholesterol } & \multicolumn{3}{|c|}{ Total lipids } & \multicolumn{2}{|c|}{ Total lipids } \\
\hline & $\begin{array}{l}\text { : ejaculate } \\
\text { volume }\end{array}$ & $\begin{array}{c}\text { : sperm } \\
\text { concentration }\end{array}$ & $\begin{array}{l}\text { : sperm } \\
\text { motility }\end{array}$ & $\begin{array}{c}: \\
\text { TNS }\end{array}$ & $\begin{array}{c}: \\
\text { TNMS }\end{array}$ & $\begin{array}{l}\text { : ejaculate } \\
\text { volume }\end{array}$ & $\begin{array}{c}\text { : sperm } \\
\text { concentration }\end{array}$ & $\begin{array}{l}\text { : sperm } \\
\text { motility }\end{array}$ & $\begin{array}{c}: \\
\text { TNS }\end{array}$ & $\begin{array}{c}: \\
\text { TNMS }\end{array}$ \\
\hline V.1999 & -0.02 & $-0.54++$ & 0.20 & -0.34 & -0.33 & 0.04 & 0.01 & -0.05 & 0.03 & 0.01 \\
\hline VI.1999 & 0.06 & 0.26 & 0.26 & 0.13 & 0.12 & 0.27 & -0.36 & 0.30 & 0.01 & 0.03 \\
\hline VII.1999 & -0.02 & -0.17 & -0.04 & -0.18 & -0.17 & -0.09 & 0.01 & 0.16 & -0.10 & -0.08 \\
\hline VIII. 1999 & -0.10 & 0.13 & 0.28 & -0.02 & 0.02 & -0.14 & -0.24 & 0.11 & -0.32 & -0.32 \\
\hline JX.1999 & -0.11 & 0.02 & 0.14 & -0.15 & -0.14 & 0.45 & -0.27 & 0.23 & 0.14 & 0.14 \\
\hline X.1999 & 0.02 & -0.38 & 0.04 & -0.30 & -0.30 & 0.14 & .0 .12 & 0.01 & 0.07 & 0.08 \\
\hline XI.1999 & -0.24 & 0.23 & 0.34 & -0.14 & -0.12 & 0.04 & -0.14 & 0.06 & 0.00 & -0.02 \\
\hline X1I.1999 & 0.35 & -0.16 & -0.03 & 0.24 & 0.37 & -0.15 & 0.13 & -0.29 & 0.01 & -0.17 \\
\hline I. 2000 & 0.15 & 0.07 & $-0.45+$ & 0.16 & 0.10 & $\because 0.40+$ & -0.15 & -0.14 & $-0.43+$ & $-0.47+$ \\
\hline II. 2000 & 0.31 & -0.02 & 0.12 & 0.38 & $0.44++$ & -0.27 & -0.20 & 0.26 & -0.38 & $-0.40+$ \\
\hline III. 2000 & -0.14 & -0.03 & 0.25 & -0.18 & -0.15 & 0.19 & 0.26 & 0.34 & 0.19 & 0.23 \\
\hline IV.2000 & 0.28 & -0.26 & 0.27 & 0.16 & 0.16 & -0.01 & -0.27 & -0.07 & -0.11 & -0.11 \\
\hline Total & $0.24++$ & $-0.25++$ & $0.25++$ & 0.09 & 0.03 & 0.13 & -0.11 & 0.13 & -0.01 & -0.03 \\
\hline
\end{tabular}

$+\mathrm{P}<0.05 ;++\mathrm{P}<0.01$ 


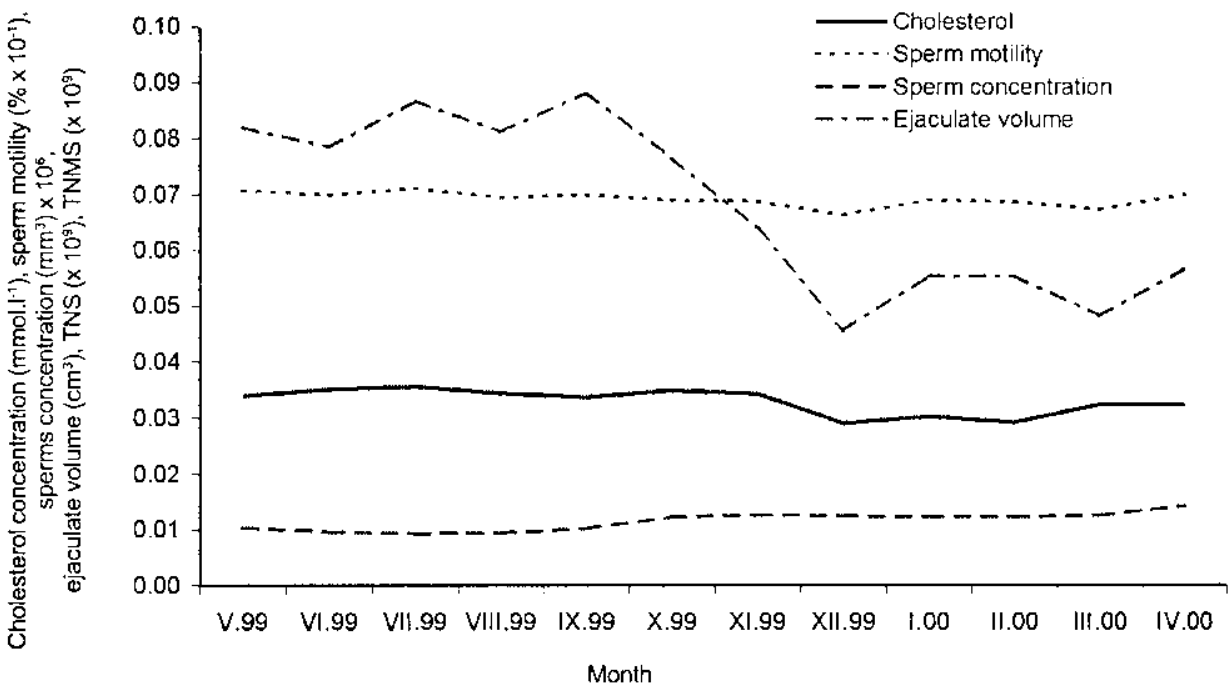

Figure 2. The blood cholesterol and the qualitative indicators in the ejaculates of the bulls (V.99 IV.2000)

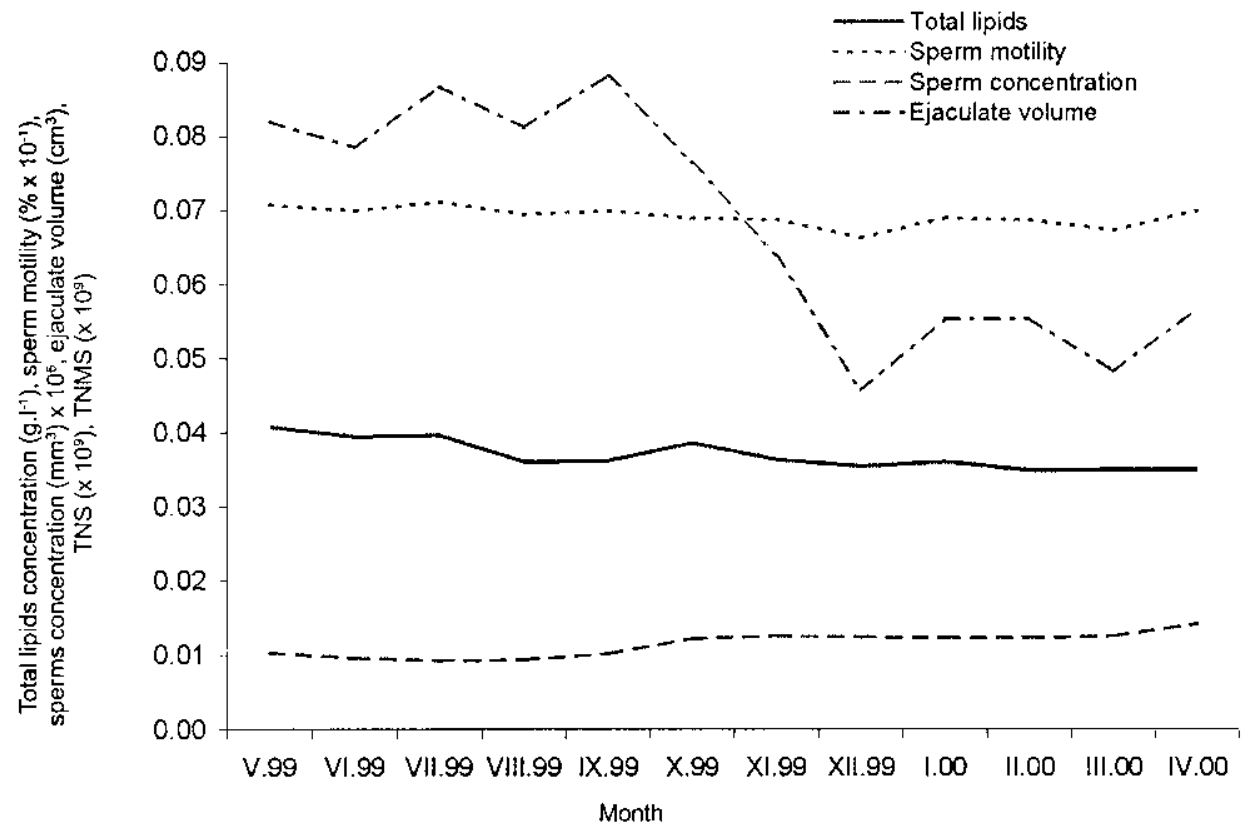

Figure 3. The blood total lipids concentration and the qualitative indicators in the cjaculates of the bulls (V.99 - IV.2000) 


\section{REFERENCES}

Alvarez J.L., Zaldivar V., Colome, H., Mayari R., 1986. Haematochemical indicators in A.I. bulls. 1. Effect of season. Rev. Salud Anim. 8, 287-294

Bulla J., Antal J., Kolataj M.A., Letkovičová M., Lezaková E., 1991. The effect of genotype and environment on some indices of fat metabolism in cattle. XV. Genetic days, Ceské Budějovice (Czech Republic), p. 221

Máchal L., Chládek G., Žižlavský J., 1999. Rclation among blood plasma total lipids, cholesterol, glucose and urea concentrations, and reproductive performance in Bohemian spotted cows. J. Anim. Feed Sci. 8, 209-221

Oprządck J., Dymnicki E., Oprządek A., 2000. Biochemical indicators in the blood plasma of young Friesian bulls (in Polish). Med. wet. 56, 316-319

Santos M.D., Torres C.A.A., Valadares S.D.C., Cenon P.R., Fonseca F.A., 1998. Testosterone profile and lipid metabolite concentrations of Zebu Bulls fed with two levels of concentrate and lipids. Braz. J. Anim. Sci. 27, 620-626

Scoane J.R., Lapierre H., Roy G.L., 1999. The use double-muscled cattle breeds in terminal crosses: animal performance and blood metabolites. Can. J. Anim. Sci. 79, 293-299

Stevanovič J., Stojič V., Gadanski-Omerovič G., Citič J., 1997. Some quantitative and qualitative characteristics of serum lipoproteins in bovine seminal plasma. Acta vet. Beograd 47, 185-194

Vrzgula L., 1990. Disturbances in nitrogen metabolism in farm anima!s and their prevency (in Slovak). Príroda, Bratislava, pp. 494

\section{STRESZCZENIE}

\section{Zależność pomiędzy stężeniem cholesterolu i tluszczu ogólnego w plazmie krwi a wskaźnikami jakości nasienia u buhajów rasy holsztyńskiej i czeskiej srokatej}

Przez 12 miesięcy badano zależność pomiędzy stężeniem choresterolu i thuszczu ogólnego w plazmie krwi a wskaźnikami jakości nasienia u 24 buhajów hodowlanych (13 rasy holsztyńskiej i 11 czeskiej srokatej). Nie stwierdzono statystycznie istotnych różnic w stężeniu cholesterolu (3,35

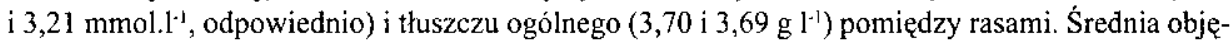
tość ejakulatu była o $1,15 \mathrm{~cm}^{3}$ (t.j. o $18,4 \%$ ) większa u buhajów holsztyńskich niż czeskich $(7,39$ i $6,24 \mathrm{ml}$, odpowiednio). W badanym okresie (12 miesięcy) stwierdzono wysoce istotną $(\mathrm{P}<0,01)$ korelację pomiędzy stężeniem cholesterolu w plazmie krwi a następującymi cechami nasienia: ruchliwością plemników $\left(r_{p}=0,25\right)$, objętością ejakulatu $\left(r_{p}=0,24\right)$ i koncentracją nasienia $\left(r_{p}=-0,25\right)$. Współczynniki pomiędzy zawartością tłuszczu ogólnego w plazmie krwi a powyższymi wskaźnikami były podobne $i$ wynosiły, odpowiednio, $r_{p}=0,13 ; 0,13 ;-0,11, i$ były statystycznie nieistotne. 